\title{
Developing A Reading Project Assessment to Stimulate Students' Critical Thinking and Creativity
}

\author{
Aldin Ramdani $^{1 \bowtie}$, Dwi Anggani Linggar Bharati ${ }^{2}$, Januarius Mujiyanto ${ }^{2}$ \\ 1. CLT Unika Semarang, Indonesia \\ 2. Universitas Negeri Semarang, Indonesia
}

\begin{tabular}{l}
\hline Article Info \\
\hline Article History: \\
Recived 28 July 2021 \\
Accepted 4 October \\
2021 \\
Published 23 \\
December 2021 \\
\\
\hline Keywords: \\
Speaking, English \\
speaking diffculties, \\
psychological \\
problems.
\end{tabular}

\begin{abstract}
Assessment is a part of the learning assessment phase of the teaching and learning process. It is used to evaluate whether the education goals have been reached by looking at the process and product of learning outcomes. However, many teachers need assistance in developing a suitable assessment system and instrument. Then it should be in line with the teaching and learning priorities of the 2013 curriculum, which enable teachers to challenge students' analytical and creative thinking. This study aimed to explain the development of project-based reading assessments to stimulate students' critical thinking and creativity of the tenth graders of X IPS 3 at SMAN 12 Semarang during the academic year 2018/2019. To construct project-based reading assessments, the researcher and the teacher collaborated. The module was revised based on expert advice until the main field testing was completed. The data collection methods were using a questionnaire, interview, observation, and examination to obtain quantitative and qualitative data. The study discovered that when students were given project-based reading assessments, their scores increased. According to the results of a paired sampled test, the students' mean score changed significantly after the post-test relative to the pre-test. Students' comprehension skills, critical thinking, and creative thinking have all improved as a result of project-based reading assessments. In conclusion, the project based assessment is applicable for teaching learning activities to stimulate high school students' critical thinking and creativity.
\end{abstract}

\footnotetext{
ॠCorrespondence Address:

J1. Menteri Supeno No.35, Mugassari, Kec. Semarang Sel., Kota

Semarang, Jawa Tengah 50249, Indonesia

E-mail : aldin.ramdani165@gmail.com
}

p-ISSN 2087-0108 


\section{INTRODUCTION}

Nowadays, the 2013 curriculum has been implemented in almost every school all over Indonesia. The teaching methods mandated in the curriculum are scientific approach (SA) (including development of attitudes, knowledge and skills). SA consists of five steps: observing, asking, collecting information, associating, and communicating. Genre-based text is the beginning point for defining the material for the students. The content chosen must be appropriate for the communicative abilities, understanding, and text structure. Furthermore, such evaluation is required in order to recognize students' success in learning. It is also used to assess how well a teaching and learning program is doing. Formal and informal assessments, as well as summative and formative evaluations, are all possible. Organizing a successful evaluation is not a simple task; it necessitates a great deal of focus. Assessments are not only resources for teachers to track students' progress, but they also enable students to see their own level of proficiency. Students may also monitor their own success.

Assessment in the learning process is an effort to acquire information related to essential variables in learning as the basis of decisions that teachers need to take in order to improve their teaching processes and, hence, improve the achievements of their students (Herman \& Zuniga, 2002; Popham, 1995). In other words, assessment is collecting information, investigating the data, and then using it to have some kind of evaluation (Morrow et al., 2010).

One of the objectives of the assessment is to determine student achievement and the effectiveness of the learning process because the assessment tool must be able to reveal overall student achievement (Yuberti, 2016). Because judgment is very strong, therefore, good judgment must be taken into account to build a fair and valid judgment. Assessment is often considered an important instructional step (Bachman, 1990). The way students are taught and the activities carried out in the classroom are greatly influenced by assessment. Furthermore, Fulcher (2003) said that the success of a learning program is usually determined by the results of the assessment. On the other hand, any skill must have an assessment to do, including in languages.

One of the language skills learnt in language is reading. Teachers need some assessments in reading for teaching and learning activities. To make better treatment, it is needed to develop reading assessment. The goal of developing reading assessments is to encourage high school students to think critically and creatively, with three types of high order thinking: content thinking, critical thinking, and innovative thinking (Crawford \& Brown 2002). A study and an estimation of the study's results are required components of the 2013 curriculum implementation.The assessment is also used to complete the learning activity. The match and effectiveness of learning and assessment have a big impact on 2013 curriculum implementation success.

It becomes a big problem when the teacher should master all the teaching methods from the past era to the post-modern era. As the government always does, different policies and changing approaches Furthermore, the class needs some treatments to stimulate students' skills if the learning and teaching work well. Here, the teachers need to maximize their roles. As the teacher's role is as facilitator, the teacher guides the students in learning and accompanies them during class. The teacher should direct the students to observe, mark, synthesize, evaluate, revise, and so on in the learning process. That the teacher should do an assessment during the teaching learning process occurs.

Arranging good assessment is not easy; it requires a lot of attention. Assessments are not only tools to help teachers measure students' progress but also provide the students with a view of their level of competencies. Students can also measure their own progress. Intentionally, the assessments will be done to support critical thinking and creative thinking.

Retnawati et al., (2016), Irfan, Sugiharto, and Hidayah (2017), and Maba and Mantra (2017) conducted a study to assess the extent of perceived differences in the way teachers applied the empirical approach to learning at the K13 
target schools. Teachers had not fully adopted the scientific method because they did not fully understand the evaluation framework, according to the report. The pattern of implementation was neither consistent nor sufficient. The teachers' comprehension of the need for scientific method pattern management in K13 was lacking. Teachers found it was difficult to develop the attitude instrument, execute the authentic evaluation, formulate the measurements, build the appraisal rubric for the skills, and collect the scores from different measurement techniques. Furthermore, the teachers were unable to come up with a practical application for explaining the students' learning achievements. Prior to introducing the teaching and learning processes in the classroom, the teachers planned lesson plans. Teachers did encounter some challenges in performing the evaluation, such as the limited time they have to observe students' social attitudes and writing the assessment results, which take a long time to explain the students' skills.

Finally, based on the discussion above, it is clear that the instructor's assessment model will influence students' learning outcomes during the teaching and learning process. As a result, the research into the implementation of the evaluation model was critical. In this study, the researcher attempted to research the teacher's assessment model and develop it, especially in the creation of a project-based assessment model to promote critical thinking and innovation in students' reading skills.

\section{METHODS}

The Research and Development (R\&D) design was used to stimulate students' critical thinking and imagination in the project-based reading assessment model in this study. Knowledge gathering, needs review, preparing and designing, expert confirmation, doing the first revision, trying out, doing the second revision, and creating the final product were the steps of R \& D used in this study.

The researcher used questionnaires, interviews, observations, and experiments to gather information. The information was qualitative as well as quantitative. Observation, interview, and a questionnaire were used to collect qualitative data. The quantitative data, on the other hand, was gathered through tests.

\section{RESULTS AND DISCUSSIONS}

In this phase, the researcher discusses the results and discussion of the developing reading project-based assessment module, which was intended to enhance students' critical thinking and creativity. In this case, it can be seen in the research objectives.

\section{Teacher's Assessment on Students' Reading Performance}

The findings of the study revealed that the teacher did not use project-based reading in the classroom and did not establish assessments based on the program. The tutor, on the other hand, tended to take a scientific approach. However, the instructor did not do it correctly, and the teacher was still in charge of the teaching and learning activity process. In fact, the teaching-learning activities were instructorcentered, since the teacher directly instructed and communicated the material to the students, rather than serving as a facilitator who supported and assisted the students in learning through scientific approach steps. The instructor often seemed to concentrate more on the subject matter and reading aloud during class. The instructor assigned students to a variety of reading tasks relating to the subject matter, such as material, generic structure, and textual features.

Another result showed that the instructor had difficulties in realizing high-order thinking skills (HOTS) into practice. HOTS are not included in the teacher's reading testing procedures. With no additional HOT questions lists for guidelines, the instructor simply asked the students to mention and retell a narrative tale. In this form of evaluation, students may memorize the text in order to complete the assignment. In addition, the instructor only used criteria like intonation, pronunciation, content, and grammar as a guide when grading the students' work. The 
researcher was unable to locate the critical thinking and imagination scoring rubric in the teacher's teaching plans because the teacher did not include HOTS in the evaluation.

These results revealed that a teacher's limited knowledge of high-order thought and its application had an effect on the teacher's ability to teach learning activities. Furthermore, the teacher did not include HOTS in the reading evaluation and did not have ranking rubrics for critical thinking and imagination. This finding is consistent with the findings of Zaim (2017), Wijayanti (2015), and Retnawati et al., (2016), who found that English teachers were not prepared to use a scientific approach in their instruction, particularly in the assessment process, and that teachers struggled to create an attitude instrument, introduce authentic assessment, formulate metrics, and design the assessment, (Hidayat et al., 2019).

\section{Types of assessments that encourage students to think critically}

Critical thought, according to Norris \& Ennis (1989) on Brookhart (2010), is rational, analytical thinking that is based on determining what to believe or do. According to Fisher (2001), critical thinking is a way of thinking about any topic, substance, or problem in which thinkers improve the standard of their thinking by skillfully taking over and imposing conceptual standards on thinking constructs. Project-based learning and project-based evaluation are two ways to help students improve critical thinking skills. According to Shakirova (2007), the presence of critical thinking skills in students can allow them to deal effectively with social, science, and practical issues (Hidayat et al., 2019).

The instructor will use instructional approaches to involve students in the learning process and develop their critical thinking skills in reading (Snyder \& Snyder, 2008), such as debates and role-playing games, to help students' comprehension of narrative text reading ability (Putra 2014). Students were asked to form a small group, similar to how the instructor did, in which all participants could express their thoughts, views, suggestions, or anything else they had to say. They will see everyone's point of view and learn new insights to gain a deeper understanding of a situation. Learners can only complete their internal learning processes by cooperating with friends or peers who are capable of doing so, according to Vygotsky's theory (Vygotsky 1978).

Furthermore, based on their research support, Wang and Seepho (2017) stated that group discussion improved students' higher-order thinking skills. Finally, this finding supports the notion that engaging in group discussions will help students improve their critical thinking skills.

\section{Types of assessments that encourage students to think creatively}

To encourage students' imagination, teachers must be creative by being good planners (designing lesson plans with appropriate techniques), executors (paying attention to students' characteristics throughout the teaching process), evaluators (giving positive feedback), and open-minded people (Lestari et al., 2018).

HOTS questions can be used by the instructor to encourage students' imaginative thinking by requiring them to plan future actions if they transform into the characters in the story and modify or vary certain aspects of the story depending on their imagination. Students may practice discussing the story from a certain perspective or viewpoint using these types of questions. It is an opportunity for them to expand their mental horizons and develop a fantastic mind. It will, without a doubt, inspire imagination in terms of adding variety to the story by suggesting various concepts based on their thoughts.

Developing a learning model that teaches students how to discover from previously learned problems and experiences will help them develop an innovative mindset (Rahman, 2017). According to Hassan et al., (2016), using HOTS objects in the assessment would test students' cognitive capacity to use information to generate or conceive of new ideas and ways of doing things (Wahyudi et al., 2019). 
Developing a Project-Based Reading Assessment to Encourage Critical Thinking and Creativity in Students

The researcher collaborated with the teacher to create a project-based reading evaluation module to encourage critical thinking and imagination in the students. The basic competencies, which were 3.5 and 4.5 , were described first, and then developed into indicators. Following that, the instructor scheduled six meetings to introduce the evaluation module, which included a lesson plan, instructional materials, and scoring rubrics for critical thinking and innovation. Before using the established project-based reading assessment in the classroom, the researcher asked experts to validate it. The project-based evaluation was able to be completed after many evaluations as recommended by the expert. The application of the project-based reading assessment began with the administration of a pre-test to the students at the first meeting in order to identify their critical thinking skills prior to the treatments. Finally, after several treatments, the students completed a post-test at the last meeting to assess their critical thinking skills.

This module used high-order reasoning questions to encourage students to think critically. The HOTS questions allowed students to document what they had observed, attempted, and objectively commented on, such as identifying similarities between two narrative texts, answering questions, and fully comprehending and evaluating the text to reach a conclusion. The questions should be constructed in such a way that they encourage the examination and synthesis of facts and concepts. By posing questions that enable students to not only search or retrieve information, but also interpret, logically process, apply, and assess it (Walker, 2003), teachers may help students develop critical thinking skills. Additionally, students should work in pairs or classes, with or without instructor guidance, to negotiate responses to questions posed (Iakovos, 2011).

Students were engaged in activities that required them to modify parts of the story based on their imaginative thinking, such as encouraging them to create various resolutions to the story and asking them to suggest alternate behavior as if they were the protagonists in the story, in order to encourage their creative thinking. Creativity can develop naturally when in practice processes (Treffinger's Model 1980). Working on real-world issues also adds to the degree of creativity and execution (Nuraida 2016).

Hamza and Griffith (2006), Ritter and Mostert (2017), Tan et al., (2016), and Zabihi et al., (2013) all agree that the vague questions that force students to think creatively are what lead to an imaginative, unusual approach or new concept for the situation. Furthermore, imagination is a product of students' creative thought processes.

\section{The Impact of Project-Based Reading Assessment on Critical Thinking and Imagination in Students.}

The results of the students' pre-test and post-test showed that their performance had improved. The students' average pretest score was 42.67. The students' mean score increased to 60.13 on the post-test. A paired sample test is used to examine the changes in the students' scores. The sig ( 2 tailed) meaning $(0.00)$ is less than 0.05 , according to the t-test results. This meant that there had been a substantial change. As a result, it's safe to say that project-based reading assessment helped students develop their reading skills.

The success of the project-based evaluation module in improving students' reading ability should be measured in terms of critical thinking and imagination. As a result, the researcher looked at the students' critical thinking scores before and after the test. The students' mean pretest score was 47.83 , while their post-test score was 70.83 . The critical thinking score of the students seems to have improved. The researcher then used a paired sample test to see if the changes were meaningful. The sig (2 tailed) meaning $(0.00)$ is less than 0.05 , according to the t-test results. As a result, it's reasonable to conclude that students' critical thinking skills improved significantly after they were treated 
with project-based reading evaluation. According to Hanardi (2015), a project-based model will increase students' involvement in the learning process. Project-based learning, according to Jusmaya and Efyanto (2018), would develop critical thinking skills. Project-based learning has also been shown to improve students' critical thinking skills (Saripudin et al., 2015).

Finally, the researcher looked at the students' creative thinking scores before and after the test. In the pre-test, the students' average creativity score was 42.67 . The students' mean post-test score was 60.13 after the treatments. As a result, it is possible to conclude that the students' results improved after they were treated with a project-based reading evaluation module. The researcher then performed a paired sample test, and the t-test result revealed that the sig (2 tailed) value $(0.00)$ is less than 0.05 . It means that the students' creativity improved significantly after they were treated by the module. Finally, the project-based reading evaluation module is successful in increasing student imagination. According to Lestari et al., (2018), project-based assessment is a successful way to develop students' critical thinking and innovation. According to Jusmaya and Efyanto (2018), project-based learning will help students improve critical thinking skills. Students' critical thinking skills have also been shown to develop as a result of project-based learning (Saripudin et al., 2015). In addition, incorporating Project-Based Learning into science education may aid students in developing creative thinking skills (Yamin et al., 2020).

\section{CONCLUSIONS}

Preliminary findings reveal that English teachers did not use a project-based learning approach because the teacher was more comfortable with traditional teaching and learning methods. As a result, the teachers tended to use a scientific approach in their teaching strategies. However, in the teaching materials, the researchers did not find the right assessment tool to improve students' critical thinking and imagination. The researcher also noticed that the teacher preferred to do it the same way because they were more focused on the subject matter. As a result, it can be inferred that the instructor did not use HOTS evaluation in the classroom to stimulate students' critical thinking and imagination.

The researcher and the teacher were able to construct a project-based reading assessment module as a result of their collaboration. In a number of ways, this evaluation module seeks to stimulate critical thought and creativity in students. To begin, students' critical thinking was piqued by having them find similarities between two stories and by having them answer HOTS questions with implied answers. Second, students' imaginative thinking was sparked by asking them to alter the story by having a different ending. Students have participated in a group discussion. Finally, they should give a presentation in front of the class about their ideas.

The researcher then performed a pretest and post-test to demonstrate that the discoverybased speaking assessment module was successful in stimulating students' critical thinking and imagination. According to the study's findings, students' average performance increased in the post-test compared to the pretest. The paired sample test results showed that the improvements were important. The major gains show that the project-based evaluation module is successful in improving students' reading, critical thinking, and creative thinking abilities.

Finally, the findings indicate that a projectbased reading assessment module will help students to develop their critical thinking and imagination. Furthermore, the researcher encourages English teachers to create their own tests in order to promote critical thinking and imagination in their students. Finally, the researchers hope that this research will inspire future research in the same area at different educational levels and perspectives. 


\section{REFERENCES}

Bachman, L., F. (1990). Fundamental considerations in language testing. New York: Oxford University Press.

Brookhart, S. (2010). How to assess higher-order thinking skills in your classroom. Alexandria, VA: ASCD.

Crawford, C. M., \& Brown, E. (2002). Focusing upon higher-order thinking skills: WebQuests and the learner-centered mathematical learning environment. (ED 474086) ERIC..

Fisher, A. (2001). Critical thinking: An introduction. UK: Cambridge University Press.

Fulcher, G. (2003). Testing second language speaking. London: Longman/Pearson Education.

M. K. Hamza and K. G. Griffith. (2006). Cultivating a creative mind: problem solving and creative thinking in the classroom. Journal of the National Forum of Applied Educational Research, 19 (3), 1-30.

Hanardi, L.G. (2015). A project - based assessment model of english for senior high school grade. Indonesian Journal of English Language Studies, Vol 1. No 1, March 2015.

Hassan, S. R., Rosli, R., \& Zakaria, E. (2016). The use of i-think map and questioning to promote higher-order thinking skills in mathematics. Creative Education, 7, 10691078.

Herman, J., \& Zuniga, S. (2002). Performance assessment. Farmington Hills: The Gale Group Inc.

Hidayat, Rifki N.L., Rukmini. D., Bharati, D.A.L. (2019). Developing problemsolving based assessment to stimulate critical thinking and creativity of students' writing skill. English Education Journal, 9 (2) (2019) $164-171$.

Iakovos, T. (2011). Critical and Creative Thinking in the English Language Classroom. International Journal of Humanities and Social Science, 1(8), 82-86.

Lestari, Tutik., Dwi Anggani L.B., Dwi Rukmini. 2018. Developing project-based writing assessment module to stimulate students' critical thinking and creativity. English Education Journal (EEJ), 8 (4) (2018) 499 - 507.

Maba, W., \& Mantra, I.B.N. (2017). An Analysis of assessment models employed by the Indonesian elementary school teachers. International Journal of Social Sciences and Humanities, 1 (1) 39-45.

Irfan, M., Sugiharto, S., \& Hidayah, T. (2017). The implementation of scientific approach to the pjok learning at the target secondary schools of the 2013 curriculum in North Sumatra. The Journal of Educational Development, 5 (1) (2017) 12 - 18.

Jusmaya, A., \& Efyanto, W. (2018). Empowering Students' Critical Thinking by Applying Project Based Learning. Jurnal Pendidikan Bahasa Sastra dan Seni, Vol. 19 No. 2.

Morrow, Angela, M., Quine, Susan., Heaton, Maria, D., \& Craig, Jonathan C. (2010). Assessing quality of life in paediatric clinical practice. Journal of Paediatrics and Child Health, Volume 46, Issue 6 p. 323328.

Nuraida. (2016). The effect of creative teaching technique to creative problem-solving ability in students. TARBIYA: Journal of Education in Muslim Society, 4(1), 2017, 53-62.

Popham, W. J. (1995). Classroom assessment: What teachers need to know (5th ed.) Pearson/Allyn \& Bacon.

Putra, P. (2014). The correlation of playing roleplaying games and students' reading comprehension of narrative text. Journal of English and Education, 2(2), 56-57.

Rahman, M. H. (2017). Using discovery learning to encourage creative thinking. International journal of social sciences \& educational studies. 4 (2), 98-103.

Retnawati, H., Hadi, S., \& Nugraha, A. C. (2016). Vocational high school teachers' difficulties in implementing the assessment in curriculum 2013 in Yogyakarta province of Indonesia. International Journal of Instruction, 9 (1), 33-48.

Ritter, S.M., \& Mostert, N. (2017). Enhancement of creative thinking skills using cognitive- 
based creativity training. Journal of Cognitive Enhancement, 1, 243-253.

Saepudin, A. (2020). Project based learning implementation to students scientific attitude and creativity improvement. Jurnal Mangifera Edu, Vol. 5 No. 1.

Saripudin, A., Haryani, S., \& Wardani, S. (2015). Charaterized project based learning to improve critical thinking skill. International Conference on Mathematics, Science, and Education.

Shakirova. (2007). Technology for the shaping of college students' and upper-grade students' critical thinking. Russian Education \& Society, 42-52.

Snyder, L. G., \& Snyder, M. J. (2008). Teaching critical thinking and problem solving skills. The Delta Pi Epsilon Journal, Vol. 50 (2), 90-99.

Tan, L. S., Lee, S. S., Ponnusamy, L. D., Koh, E. R., \& Tan, K.C.K. (2016). Fostering creativity in the classroom for high ability students: Context does matter. Education Sciences, 6 (4), 36.

Vygotsky, L.S. (1978). Mind in Society: The development of higher psychologycal process. Cambridge, MA: Harvard University Press.

Treffinger D. J. (1980). Encouraging creative learning for the gifted and talented: A handbook of methods and techniques. Ventura: Ventura Country Superintendent of School Office.

Wahyudi, R., Rukmini, D., Bharati, D.A.L.. (2019). Developing discovery learningbased assessent module to stimulate critical thinking and creativity of students' speaking performance. English Education Journal, 9 (2) (2019) 172 - 180.

Walker, S. E. (2003). Active learning strategies to promote critical thinking. Journal of Athletic Training, 38(3), 263-267.

Wang, S., \& Seepho, S. (2017). Facilitating chinese EFL learners' critical thinking skills: The contributions of teaching strategies. SAGE JOURNAL.

Wijayanti, Y. R. (2015). An evaluation model of problem-based learner assessment in curriculum 2013. Indonesian Journal of English Language Studies, 1(2), 207-219.

Yamin, Y., Permanasari, A., Redjeki, S., \& Sopandi, W. (2020). Implementing project-based learning to enhance creative thinking skills on water pollution topic. Jurnal Pendidikan Biologi Indonesia, 6 (2), 225-232.

Yuberti., Nomida, D., \& Nuriah, T. (2016). The assessment of student performance in the practicum activity of basic physic course. TARBIYA: Journal of Education in Muslim Society, 3(1), 121-130.

Zabihi, R., Rezazadeh, M., Dasrjerdi, H.V. (2013). Bellaterra Journal of Teaching \& Learning Language \& Literatur, 6 (3): 29-46.

Zaim, M. (2017). Implementing scientific approach to teach english at senior high school in Indonesia. Asian Social Science, 13 (2), 33-40. 